\title{
Yeni Medya Çağında Haberleri Yeniden Düşünmek: Teknoloji İle İçeriğin Kesişmesi ve Yenilikçi Davranışlar
}

\author{
Rethinking the News in the New Media Age: Intersection of Technology and Content and Innovative \\ Behaviors
}

Kenan Duman

Görsel İletişim Tasarım Bölümü, Arel Üniversitesi, İstanbul, Türkiye

\begin{abstract}
Özet
Teknolojik anlamda özellikle bilgisayar teknolojilerinde ki gelişmelerle habercilik alanı son 20 yıl içerisinde büyük bir dönüşüme uğramıştır. Kâğıt bazlı habercilik giderek gerilerken habercilik alanı dijital platformlara kaymıştır. Haber Merkezleri okuyucu için daha iyi bir gazetecilik deneyimi oluşturmak için yeni yollar denerken teknoloji ile içeriğin kesiştiği bu yeni alan da yenilikçi davranışların ortaya çıkmasında haber odalarının özerkliği, çalışma kültürü, yönetim, teknoloji ve yenilikçi bireylere olan ihtiyaç önem arz etmektedir. Bu çalışmanın amacı haber merkezlerinde ki yenilikçi davranışları Türkiye özelinde tartışmak ve internet medya profesyonellerinin haber oluşturma pratiklerinde yarattığı dönüşümü saptamaktır. Bu amaçla çalışmanın sorunsalının sınanması için veri toplama tekniği olarak Türkiye'de Internet medyası çalışanları ile derinlemesine mülakat gerçekleştirilmiştir. Bu mülakatlar ile gazetecilik sektöründe yenilikçi davranışların neler olduğu ortaya konulmuştur. Araştırmada ayrıca çevrimiçi haber merkezlerinde çalışanlarının haber odası çalışma rutinleri ve teknoloji bağlamında eğilimleri saptanmaya çalışılmıştır. Çalışma da özellikle teknolojinin haber yazım biçiminde dönüşümde önemli bir faktör olduğu ortaya çıkmış ve haber odasında çalışma kültürünün yeniliklere açık bireyler tarafından yürütüldüğü tespit edilmiştir.

Anahtar kelimeler: Yeni Medya, Yeni Gazetecilik, Gazetecilik, Inovasyon ve Gazetecilik, Internet Haberciliği
\end{abstract}

\section{Abstract}

In the technological sense, particularly in computer technology, the field of journalism has undergone a great transformation in the last 20 years. As paper-based journalism gradually declined, the field of journalism has shifted to digital platforms. While News Centers are trying new ways to create a better journalistic experience for readers, this new area where technology and content intersect, the need for the autonomy, the working culture, the management, the technology and the innovative individuals of the news rooms is important for the emergence of innovative behaviors. On this study we aimed to discuss innovative behaviors in news centers in Turkey and to identify the transformation that internet media professionals have made in their news production practices. For this purpose, we conducted an in-depth interview with internet media employees in Turkey as a data collection technique for testing the problematic of the study. With these interviews, we revealed what innovative behaviors are in the journalism sector. We also attempted to identify trends in newsroom work routines and technology context in online news centers. In the study it was found out that the technology has an important role in the transformation of news writing format and the work cultures in the newsrooms are carried out by the individuals who are innovative.

Keywords: New Media, New Journalism, Journalism, Innovation and Journalism, Internet Journalism
JEL Codes:
L82,
Q55 


\section{Giriş}

Çevrimiçi gazetecilik olarak da bilinen internet gazeteciliği kısa süre içerisinde hızla gelişirken geleneksel gazeteciliğin ana davranışlarına benzer şekilde hareket etmeye başladı. İnternetin özelliklerinden kaynaklı haber sürecini dönüştüren farklılıklarla geleneksel gazetecilikten ayrılan internet haberciliğinin tanımlanmasında teknolojik bileșen belirleyici bir rol oynadı. (Alemdar, Uzun, 222) 1993 y1lında internet teknolojilerinde kullanıcı dostu web tarayıcılarının kullanıma başlanmasından kısa bir süre sonra ilk çevrimiçi gazetecilik web siteleri yayınlarına başladılar. Amerika kıtasından yayılan internet haberciliği ilk başlarda basit ve statik bir web siteleri iken 1994 yılına gelindiğinde küresel büyük medya içerik sağlayıcılar tarafından kullanılmaya başlandı. İnternet medyasının başlangıç dönemi çalışmaları geleneksel medyanın baskın davranışları nedeniyle çoğunlukla yazılı basının sayfalarının internete aktarması şeklinde olur. 1995 yılına gelindiğinde küresel çağlı Amerikan basın kuruluşları New York Times ve The Washington Times aynı y1l Avrupa'da da International Herald Tribune ve Daily Mirror gibi gazeteler sayfalarını internete aktardılar. (Kalsın, 2016)

Teknolojik anlamda özellikle bilgisayar ve internet teknolojilerindeki gelişmelerle habercilik alanı son 20 yıl içerisinde büyük bir dönüşüme uğradı. 1990'ların sonlarına doğru programcıların web sayfalarını hızlı ve kolay şekilde düzenlemeyi sağlayan araçlar geliştirmesi ile kolay okunabilir ve yazılabilir web sayfalarını yükselişi başlar. (Poe, 2015:378) Geçen 20 y1l gibi kısa bir süre içerisinde çevrimiçi haber içerikleri basılı yayın içeriklerine göre okura ulaşma anlamında daha ileri bir konuma gelir. Kâğıt tabanlı habercilik giderek gerilerken habercilik alanı dijital platformlara kayar. Haber Merkezleri okuyucu için daha iyi bir gazetecilik deneyimi oluşturmak için yeni yollar denerken teknoloji ile içeriğin kesiştiği yeni davranışları içeren alanlar oluşur. Bu yenilikçi davranışların ortaya çıkmasında haber odalarının özerkliği, çalışma kültürü, yönetim, teknoloji ve yenilikçi bireylere olan ihtiyaç önem arz etmektedir. Çalışmanın birinci bölümünde internet teknolojilerini yeni habercilik ortamına etkileri ve iletişim devriminin inovasyonları tartış1ırken ikinci bölümde Türkiye'de ki internet haberciliğinin tarihsel gelişiminden söz edilmektedir. Üçüncü bölümde ise teknoloji ile içeriğin kesişmesi ve yenilikçi davranışlar Türk internet haber medyası örneği üzerinden görüşmeler bağlamında incelenmiştir.

\section{Yeni Habercilik ve İletişim Devriminin İnovasyonları}

İnternet gazeteciliği geleneksel gazeteciliğin temel özelliklerini ve değerlerini yeniden yorumlayarak milenyumun hemen öncesinde büyümeye başlar. 2000 sonras 1 süreçte ise bu yeni gazetecilik türü teknolojik gelişmeler ve okur eğilimleri ile kendi özelliklerine sahip yeni bir gazeteciliğin ortaya çıkmasına neden olur. İnternet gazeteciliği kısa süre içerisinde kendi gazetecilik kodlarını oluşturur. İnternet haberciliği bu süreç içerisinde geleneksel haber tüketimini tamamlayan veya yerini alan noktaya giderken kâğıt basının durumu tartışılır hale gelmiştir. Bu durum tam olarak kanıtlanmasa bile kâğıt üzerinden gazete okumanın genelde düşüş eğiliminde olduğu görülmektedir. Pew Araştırma Merkezi (2010) tarafından yürütülen çalışmalar son 20 yıl içerisinde basılı haber tüketiminde istikrarlı bir düşüş yaşandığını göstermektedir. Yapılan çalışmalarda okurlara nereden haberlere ulaştıkları sorulduğunda 1991'de yüzde 56'lık bir oranla "gazeteden" okurum cevabı verenlerin sayısının 2010 yılına gelindiğinde yüzde 31 'e gerilediği görülür. Bu duruma karşılık okurların yüzde 34'ü 
haberlerine internet üzerinden ulaştıklarını vurgularlarken mobil medya, e-posta, sosyal medya oranlarında eklendiğinde bu oranın yüzdesinin 44'e kadar yükseldiği anlaşılır. (Pew, 2010)

Gazetecilik çalışmaları içerisinde teknolojinin yarattığı sosyo-kültürel değişimler içirişinde internet gazeteciliği araştırmaları da önemli bir yer taşımaktadır. Bu alanda başta Deuze, Domingo ve Singer olmak üzere ilk çalışmacılar üç temel konu üzerine eğilirler. Bu konular: aşırı metinlilik, etkileşim ve çok yönlülüktür. Bu ilk araştırmalar bağlı oldukları olasılıkları incelemeye ve gazeteciliğin aslında onları ne ölçüde kullandığını ölçmeye çalışmıştır. (Siapera ve Veglis, 2012: 3-4) İnternet gazeteciliği üzerine teorik çalışmaların önemli bir parçası teknoloji, toplum ve gazetecilik arasındaki ilişkiye odaklanmaktadır. Buradaki ana fikir, internet gazeteciliğinin teknolojiye bağlı olması nedeniyle bu yeni tür gazeteciliğin gelişsimini anlamanın bir aracı olarak teknoloji ile toplum arasındaki ilişkiyi keşfetmenin gerekliğidir. Bununla birlikte, teknoloji kuramları çokludur ve her biri teknoloji, toplum ve gazetecilik arasında farklı bir ilişkiyi ortaya koymaktadır. Bu anlamda bilinen en iyi yaklaşım, inovasyonların sosyal gruplar tarafindan benimsenmesi süreçlerine bakan yeniliklerin yayılması teorisidir. (Rogers, 1995) Boczkowski ise (2004) çevrimiçi haber merkezlerinde yeniliklerin benimsenmesinin örgütsel yapısal faktörlerin, çalışma uygulamalarının ve bu yeniliklerin kullanıcıların eğilimlerinin bir sonucu olduğunu ortaya koymuştur. (Siapera ve Veglis, 2012: 3-4)

Yukarıda söz ettiğimiz kuramsal perspektifler internet tabanlı yeni habercilik düzeninin başlangıcı ve gelişimi hakkındaki anlayışımızı büyük ölçüde geliştirse de haber merkezlerinin gelenekselden gelen farklı dinamiklerini göz ardı etmemek gerekir. $\mathrm{Bu}$ nedenle ilk çalışmaların katkılarına rağmen somut ortamlarda gazeteciliğin kesintisiz ve devam eden gelişimini anlamak için teorik bir kesin yorumdan kaçınmak gerekir. (Siapera ve Veglis, 2012: 12) Yeni dönemde gazeteciliği karakterize eden yapı ve süreçler, yeni dönemin okur kitlelerinin alışkanlık ve talepleri doğrultusunda kapsamlı bir değişim sürecinden geçmektedir. Bu değişen senaryo dikkate alındığında, medya işletmelerince benimsenen önemli sayıda strateji günümüzdeki gazetecilik konusundaki temel kavramlardan biri olan yakınsamaya uyum sağlama yolları olarak anlaşılabilir. Geleneksel medya ile benzerlikleri olsa da bu yeni olgunun boyutu, üretim koşullarını yeniden tanımlayan teknolojik faktör 1şığında ayrı bir tartışmayı gerektirir. Bu yeni aracın temel avantajları hem inovasyon hem de kullanıcı alanını genişletme imkânı ile açıklanırken teknoloji ile gazeteciliğin kesiştiği noktada bazı doğal sorunlar da ortaya çıkmaktadır. Bu sorunlar içerisinde en dikkat çekici olan mesleğin epistemolojik tabanını oluşturan inanılırlık olgusu gelmektedir. Haber organizasyonlarının gelenekselden çevrimiçi haber merkezlerine göre ilerledikleri süreçte haberleri süzme yeteneği olan eşik bekçiliği sürecinin giderek zayıflaması önemli bir sorun olarak karşımıza çıkmaktadır. Son iki yüz yılda kurumsallaşmasını tamamlayan gazetecilik mesleği içerisinde haberleri süzme süreci çok önemli bir yer tutmaktadır. 21. yüzyılın haberciliği ve bilgi akışı olan dijital çağın temposuyla ile medya düzeni geleneksel anlamda dönüşürken dijital teknoloji neyin haber olduğunu belirleyen merkeziyetçi ve kurumsal yapıyı değiştirmektedir. (Atikkan ve Tunç, 2010: 214) Hız, bol enformasyon ve daha az çalışan odaklı bu yeni yapı merkeziyetçiliği alt üst ederken haber doğrulaması anlamında sorunlara neden olmaktadır. 
Yakınsama kültürünün içerisinde doğan internet gazeteciliği çoklu medyalar ile çalışan bir yapıdadır. Bir haber oluşturulurken metin, fotoğraf, ses ve video görüntüsü ile aktarılabilirken etkileşimlilik esastır. Okur, geleneksel gazetecilikten farklı olarak haberlere yaptığı yorumlarla blog ve tweet gibi sosyal medya araçlarıla gazeteye katkıda bulunabilir ve tepkisini anında iletebilir. Ayrıca hiperlinkler aracılığıyla arşiv ve diğer kaynaklara ulaşılabilir. İnternetin sunduğu depalama ve arşiv teknolojileri sayesinde de hangi sayfaların ziyaret edildiği, hangi haber ya da yorumların kac kez okunduğu gibi geri bildirimler elde edilebilir. (Alemdar, Uzun, 222) Çeyrek asrın biraz üzerinde bir geçmişe sahip olan internet gazeteciliği gelişimi ve uygulama biçimi bakımından 3 döneme ayrılarak incelenebilir. Birinci dönem, geleneksel gazetelerin egemen olduğu fakat gazetecilerin haber içeriğini internet gazeteciliği için üretmedikleri, günlük gazete için üretilen haberleri gazetenin web sayfası için tekrar tasarladıkları dönem olarak özetlenebilir. Birinci dönemin izleri hala devam etmektedir. İkinci dönemdeyse, gazeteciler haber içeriğini özgün olarak sadece web sayfası için düzenlemektedirler. Düzenlenen bu içerik, okuyucunun anında çeşitli sınıflanmış haber ve enformasyonu etkileşimli olarak ulaşabilmesini sağlamaktadır. Üçüncü dönemde ise, 2000 sonrası haber merkezlerinde görülen sadece web sayfasının yeni bir iletişim mecrası olarak biçimlendirilmesidir. (Tokgöz, 2003: 82-83) Bu dönem de dikkat çeken gelişme ise günlük gazetelerin haber web sitelerinin, özel parasız haber sitelerinin kopyala yapıştır biçiminde akınıyla karşı karşıya kalmasıdır. (Maigret, 341) Özellikle istihdam ve finansman sorunu yaşayan yeni nesil haber web siteleri geleneksel haber merkezleri ve ajanslar ile beslenerek var olmaya çalışmaktadırlar.

\section{Türkiye'de İnternet Haberciliği}

1993 yılında küresel anlamda ilk örnekleri görülmeye başlayan internet haber siteleri 1995 yılı itibariyle Türkiye'de yayınlanmaya başlar. Türkiye'de 2 Nisan 1993 internetin başlangıcı olarak kabul edilir. ODTÜ'nün sunucuları üzerinden gerçekleştirdiği ilk internet bağlantısının ardından 2 yıl sonra Temmuz 1995 'de içeriğini internette yayınlayan Aktüel dergisi ilk basın kuruluşu olarak dikkat çeker. Türkiye'de içeriğini internet ortamına taşıyan ilk gazete ise Kasım 2006'da Milliyet olmuştur. Aktüel ve Milliyet gazetesini 1997 yılı başı ile Hürriyet ve Sabah gazeteleri takip eder. 1998 y1lında ise Radikal ve Cumhuriyet gazetesi internete aç1lırken bu tarihten itibaren ülkede yayın yapan başta ulusal olmak üzere yerel ve bölgesel gazeteler kendi haber sitelerini oluştururlar. Çakır, (2007) iki yıllık kısa bir süre içerisinde arka arkaya haber portallarının yayın hayatına başladığını ve sadece internet haberciliği üzerine yayıncılık yapan sitelerin sayısının 70'in üzerinde olduğunu vurgular.

Türkiye'de yayın yapan ilk internet gazetesi ise Xn (Eksen) olur. Yukarıda söz ettiğimiz kurumlar geleneksel basın kuruluşlarının devamı niteliğindeyken 1996 tarihinde kurulan ve üç yıl açık duran Xn (eksen)günlük gazeteleri tarayarak günün önemli köşe yazarlarını ve haberlerini derleyerek okura sunan bir yapıyı portal üzerinden okurlarına ulaştırır. XN'den sonra bağımsız haber sitelerinin kurulması ancak 2000 y1lında gerçekleşir. İlk haber siteleri de 'nethaber', 'habertürk' ve 'internethaber' gibi siteler olmuştur. 2000 yılına gelindiğinde geleneksel medya kuruluşları dışında internet haber sitelerinin arttı̆̆ 1 bir dönem yaşanır. Bu durumun oluşmasında özellikle basın alanında yaşanan ekonomik krizin sonucunda çok sayıda gazetecinin işten çıkarılması önemli pay oynar. Çok sayıda önemli görevlerde bulunan işsiz gazeteciler internet haber siteleri kurarak mesleklerini devam ettirmeleridir. Kalsın, $(2016,78)$ bu 
durumun Türkiye'de internet gazeteciliğinin gelişmesine olumlu katkı sağladığının altını çizer.

İnternet haberciliği 2000'li yılların ilk çeyreğinde içerik olarak batılı örneklerinin benzer stratejiler geliştirse de internet haber merkezleri kültürünün oluşturulması kolay olmaz. İlk dönem haber merkezleri geleneksel haber merkezleri içerisinde çoğunlukla birkaç içerik editörü ile yapılan ve kopyala yapıştır haberciliği denilen ajanslardan ya da haber merkezi haber havuzunda ki haberlerin eklemlendiği bir sistem olarak çalışır. 2000'li yılların ilk çeyreğinde batılı örnekleri gibi önce kopyala yapıştır gazeteciliği ile ilerlemeye başlayan internet haber merkezleri sonrasında kurumsallaşma anlamında önemli yol alırlar. Özellikle orta ölçekli geleneksel medya kurumları ile rekabet edebilir haber kuruluşlarının sayısı artar. 2010 yılı sonrası içeriğini tamamen dijitale taşıyan Radikal Gazetesi bu durumu da uzun süre sürdüremez ve bir süre sonra yayınına son vermek zorunda kalır. İlk dönem haber merkezleri içerik olarak çoğunlukla ajanslardan ve geleneksel medya kuruluşlarından beslenirken ekonomik anlamda ise geleneksel basın ekonomisi ile rekabet eder duruma gelememişlerdir.

2000 sonrası Türkiye'de internet gazeteciliği kategorisel olarak ikiye ayrılmaktadır. Geleneksel medya kuruluşlarının internet siteleri ve bağımsız gazetecilerin kurdukları haber sitelerinden oluşan bu ikili yapı ekonomik olarak geniş bir sahası olmayan alanda rekabet içindedirler. Anaakım gazetelerin internet versiyonları genellikle basılı gazetelere benzemektedir. Ancak internet versiyonlarında daha fazla haber ve köşe yazısı yer almaktadır. Bazı gazetelerin siteleri linkler, habere ilişkin çok sayıda fotoğraf, video görüntüsü ve okur yorumlarıyla internetin olanaklarını daha iyi kullanan bir görünümdedir. Bunların yanında yalnızca internet üzerinden yayın yapan haber portalları da bulunmaktadır. Bunların çoğu yukarıda da söz edildiği 2000 sonrası dönemde ana akım medyadaki kriz nedeniyle işlerine son verilen gazeteciler tarafından kurulmuştur. İlk dönemlerde internet sitesi kuran gazetecilerin büyük bölümü geleneksel medyada yetişmiş ve yeni teknolojileri kullanma ve izleme konusunda yeterli olmayan kimselerden oluşurken kurulan haber sitelerinin çalışma mantığı kopyalayapıştır haberciliği olarak nitelenmiştir. (Alemdar, Uzun)

\section{Teknoloji İle İçeriğin Kesişmesi ve Yenilikçi Davranışlar: Türk İnternet Haber Medyası Örneği}

Çalışmanın bu bölümünde internet haberciliği alanında teknolojik yeniliklerin haber içeriğine etkisini incelemek için Türkiye'de İnternet haber merkezlerinde içerik oluşturanlarla derinlemesine görüşmelerden elde edilen veriler yer almaktadır. Derinlemesine görüşme ile amaç katılımcıların bakış açısını, niyetini, tutumunu, düşüncelerini, yorumlarını ve perspektifini ortaya koymak ve ortak tutum ve düşüncelere dayalı sonuçlar çıkarmaktır. (Yıldırım ve Şimşek, 2008:120) Araştırmada haber merkezlerinde ki yenilikçi davranışları Türkiye özelinde tartışmak ve internet medya profesyonellerinin haber oluşturma pratiklerinde yarattığı dönüşümü saptamak için yenilikçi davranışların neler olduğuna ilişkin sorulara yanıtlar aranmıştır. Çalışmada örneklem olarak kartopu tekniği ile örneklem yapılarak temasa geçilen bir birimin yardımıyla ikinci birime, ikinci birimin yardımıyla üçüncü birime doğru gidilmiştir. Kartopu tekniği kullanılması nedeni olarak görüşme yapılan haber merkezi çalışanlarının geleneksel basın çalışanları gibi belirli bir ofiste bulunmamaları ve kurum içerisinde detaylı çalışan bilgilerine ulaşılamamasıdır. Örneklem kotası İstanbul 
merkezli ulusal internet siteleri olarak belirlenmiștir. Ulusal haber sitelerinin künyeleri üzerinden yapılan araştırmada 17 kişi ile görüşmeler yapılmıştır.

Görüşmeler de daha iyi sonuç alınması için görüşme yapılanların kimlik bilgilerinin saklanacağı özellikle belirtilmiştir. Bu nedenle Tablo-1'de yalnızca görevleri ve eğitim bilgilerine ilişkin bilgiler yer almaktadır.

Tablo 1: Örneklem Olarak Belirlenen Çalışanlara Ait Bilgiler

\begin{tabular}{|l|l|l|}
\hline KODLAMA & GÖREVI & EĞíiM DURUMU \\
\hline E1 & İçerik Editörü & Üniversite \\
\hline E 2 & İçerik Editörü & Üniversite \\
\hline E 3 & Genel Yayın Yönetmeni & Üniversite \\
\hline E4 & İçerik Editörü & Üniversite \\
\hline E 5 & İçerik Editörü & Üniversite \\
\hline E6 & Sosyal Medya Editörü & Üniversite \\
\hline E 7 & İçerik Editörü & Yüksek Lisans \\
\hline E 8 & İçerik Editörü & Üniversite \\
\hline E9 & İçerik Editörü & Üniversite \\
\hline E10 & İçerik Editörü & Üniversite \\
\hline E 11 & Sosyal Medya Editörü & Üniversite \\
\hline E 12 & Muhabir & Üniversite \\
\hline E 13 & İçerik Editörü & Üniversite \\
\hline E 14 & Multimedya Editör & Üniversite \\
\hline E15 & Haber Müdürü & Üniversite \\
\hline E 16 & İçerik Editörü & Yüksek Lisans Öğrencisi \\
\hline E17 & İçerik Editörü & Üniversite \\
\hline
\end{tabular}

Araştırmanın varsayımı haber odasında çalışma kültürünün oluşumunda teknoloji başat rol oynamaktadır şeklinde belirlenmiştir. Araştırmanın genel sorusu günümüz internet haber merkezlerinde çalışma rutinleri ve teknoloji bağlamında eğilimleri nelerdir? şeklinde belirlenmiştir. Genel soru bağlamında internette haber yazımının zayıf ve güçlü yönleri nelerdir? ve internet haberciliği ile ilgili çalıştı̆̆ınız haber merkezinde ne tür eğilimler vardır? sorularına yanıt aranmıştır.

\section{5. İnternette Haber Hazırlama}

Haber merkezlerinin yeni teknolojileri nasıl uyguladığını ve bu kurumsal değişikliklerin haber amaçlı olabilecek etkileri son dönem habercilik çalışmaları içerisinde büyük önem arz etmektedir. Gazetecilik için haber merkezlerinde gelecek üzerine analizlerde teknoloji ve içeriğin kesişme noktasında olacağı ve gazeteden radyoya oradan televizyona evrilen bu uzmanlık alanı için dijital kitlelerle bağlamının büyük önem arz ettiği söylenebilir. Geleneksel haber kuruluşlarının büyük oranda okur kaybettiği bu dönemde genel olarak yazılı gazetelerin büyümeye devam etmesini durdurduğu konusunda hem fikir olduğu söylenebilir. 1993'ten bu güne internet haber merkezleri ara yüz başta olmak üzere teknolojik gelişmelerinde etkisi ile başta yazı ve görsel ile başladıkları haber yazım işleminde tablolardan, infonografiye galerilerden 
sesli haber oluşturmaya video haberden mobil için haber oluşturmaya birçok aşamadan geçti. Bugün internet için haber hazırlama gazete ve televizyon ile karşılaştırıldığında hız bakımından zorluklar oluştursa da yayıncılık açısından daha kolay olarak görülmektedir. Geleneksel gazetecilik için haber hazırlama ile internet için haber hazırlama arasında ki kolaylık üzerine soruya görüşme yapılan katılımcılar büyük ölçüde "İnternet için haber hazırlamak daha kolaydır" yanıtını vermişlerdir. Aynı zamanda görüşmeciler teknik becerinin önemine de dikkat çekmişlerdir.

"İnternet için haber hazırlamak geçmiş deneyimlerim ile kıyaslarsak gazete veya televizyon için hazırlamaktan daha kolaydır. Gazete ve televizyon için daha uğraştırıcı bir haber hazırlama süreci varken internet için yapılan bir haberde, ajanslardan gelen bilgi ve fotoğrafların haber haline getirilip sayfaya yerleştirilmesi yeterli.” (E1)

"Internet odaklı haber demek daha an içerisinde okura bilgileri aktarmak demek. Çoğunlukla ajans bilgileri ile destekli habercilik eğilimi etkili internet haberciliğinde." (E4)

"Gazete ile kıyaslandığında emek bakımından daha kısa ve daha az yorucu bir süreç var internette." (E10)

"İnternet için haber hazırlama daha fazla bilgisayar bilgisi gerektiriyor. Özellikle grafik gibi unsurlarda önceden sadece yazan tarafken şimdi hem yazıp hem tablo hazırlıyoruz.” E 16

"Sadece ajans haberi eklemiyoruz. Galeriler, görseller, veri tabloları da işimizin parçası." E 14

Gazetecilik mesleği içerisinde en önemli durumlardan birisi de toplanılan haberin yazım aşamasıdır. Haber yazımında ki başarı metnin içeriğine de büyük ölçüde etkilemektedir. Gazete için başlangıçta yazı ile sonrasında görsel ile desteklenen içerik, radyoda ses ile televizyonda ise görüntü ile tanışmıştır. Gazeteler radyo ve televizyon icat edildiğinde önemli bir rekabet aracı olarak bu icatları görseler de derinlemesine içerik ve uzun yazılar ile son yüzyılda da etkisini devam ettirmiştir. Kullanıcılar geleneksel radyo veya televizyonda mümkün olmayan metinleri yeniden okuma olanağına gazeteler ile sahip olmuşlardır. Web içerikleri de gazeteleri bir ileri taşıyarak her türde içeriği gazetecilerin kullanmasına ve böylece metin, video veya ses yapmasına olanak tanımıştır. HTML formatında bu yeni basının çevrimiçi sürümlerle yeni bir medya haline gelmesini sağlanırken bu yeni habercilik ortamı kendi dilini oluştururken bir yandan da daha yüzeysel ve kısa haberciliğe yöneldi. Görüşülen isimler, internet için haber hazırlarken kısa habercilik ve hız kaygısı ile haberciliği yaptıklarını belirtmişlerdir.

"Kullanıcılar haber sitelerine ulaştıklarında uzun süre haber okumazlar. Bunun farkına vararak haber hazırlamamız gerekiyor. Bu nedenle daha kısa ve daha anlaşılır cümleler ile haber hazırlamayı seçiyoruz." (E2)

"Hızlı bir şekilde haber hazırlamak zorundayız. Gazeteler ertesi gün için habercilik yaparken biz an ile yarışıyoruz. Dikkat çekici başlıklar ve yazılar tercih etmeliyiz. Başlık seçiminden fotoğraf ve video seçimine kadar farklı olmalıyız. Çok sayıda haber sitesi arasından en çok okunan haber sitesi olmamızın en önemli nedenlerinden birisi de budur. Açık, anlaşılır ve dürüst olmak...” (E3) 
"Türk internet haberciliği içinde en sinir bozucu olay spot ile girişin aynı olması. Biz bu habercilik şeklinden uzak durmaya çalışıyoruz. Tekrar tekrar aynı konuları anlatmıyoruz. Okuyucuyu sıkmadan ve yormadan haberler oluşturuyoruz. (E4)

"Elimizden geldiği kadar haberi kısa veriyoruz. Aslında kullanıcı açısından zor olmadı. Çünkü kısa cümleler ister kullanıcı. Okumaya üşenir. Fakat sosyal medyaya gelen son güncellemeler haberi görsel açıdan aktarmamız için işimizi kolaylaştırdı. Bakarsanız insanlar artık görseller ile tatmin olmayı metin okumanın önüne geçirmiş durumda." (E5)

"İnternette haber hazırlamak ile diğer yayın organları için haber hazırlamak arasında farklar vardır. Gazetede yazıyı gazete sayfasına sığdırmak gibi kaygılar vardır. İnternet haberciliğinde istediğiniz uzunlukta yazabilirsiniz. Bu da içerik anlaminda haberi hazırlayanın elini rahatlatan bir husustur. Ancak haberi hızlı bir şekilde iletme kaygısı nedeniyle haberin dil ve anlatım açısından yeterince özenle hazırlanamamasına da neden olabilir." (E6)

"Geleneksel ile internet aslında mantık olarak aynı. Haber yazımında başlığa gelince, kısa, anlaşılır ve dikkat çekici olması haber kuralıdır." (E7)

Haberin kısa ve hız ile yarışmasına ek olarak web üzerinde bilgi yapılandırma unsuru olarak metin içi iliştirme ve hipermetin uygulamaları geleneksel haberciliğe göre bir avantaj olarak karşımıza çıtı. Web tabanlı içerik bağlayıcılar aynı haber hikâyesini okumanın birden fazla yoluna izin vererek haber öyküsünün bağlantılı bir parçası haline getirdiler. Bu uygulamaların en önemlisi link oluşturmadır. (Siapera ve Veglis 2012: 33). Görüşme yapılan editörlerin üçü haberi hazırlarken linklemenin yeni davranış pratikleri içerisinde önemine dikkat çekmişlerdir.

"Haber içi linkleme de önemli olduğu için konuyla alakalı ilişkili haberler haber içine linkleniyor. Bol fotoğraf ve videonun haber için önemli olduğu için zengin içerik üretiliyor.." E8

"Yeni rekabetçi ortam, özellikle internet haberciliğinde büyük bir dönüşüme neden olmuştur. Artık haber metinleri okuyucunun dikkatini kaybetmemek için linkleme yaparak hareket ediyorlar." (E9)

"Haberler sadece düz metinler değil. Aynı zamanda bağlantılarla birbirine eklenen yazılar. Bu bakımdan yazılı haberden daha ileride olduğunu düşünüyorum.” E 14

İnternet haber merkezleri için geleneksel haber mantığı ile önemli bir fark olarak karşımıza haber seçimi çıkmaktadır. Geleneksel ile karşılandığında daha kısa bir sürede daha az bir ekip tarafından ve eşik bekçiliği anlamında daha esnek bir çalışma prensibi ile oluşan bu yeni alan haberin oluşum biçimi bakımından bazı sorunları da beraberinde getirmektedir. Görüşülen editörlerden iki tanesi haber seçimi konusunda tıklama kaygısının daha da ön planda olduğuna işaret emişlerdir.

“....Haber seçimi konusunda seçici davranıyoruz. Gündemin yoğunluğuna bağlı olarak haberler oluşturulurken diğer yayın organlarında yer alan haberlere fazla yer vermiyoruz. Bu da okur için bir avantaj oluşturuyor. Okumadığı haberlere daha kolay erişiyor. (E4)

"İnternette haber hazırlarken okuyucunun habere tıklamasını sağlama kaygısı nedeniyle büyük hatalar yapılıyor. Bu amaçla haber başlıkları hazırlanırken haberin 
amaç ve içeriği ile bağlantısız, okuyucuda merak uyandıracak biçimde haber başlıkları hazırlanıyor. Oysa olması gereken haberlerde başlıklar, konuyu ve haberi en kısa şekilde özetleyen ifadelerden oluşturulmalıdır. (E6)

Yeniliklerin başarılı bir şekilde yönetilmesi ekonomik açıdan çalkantılı bir ortamda hayatta kalmaya çalışan haber merkezleri için büyük önem taşımaktadır. Deuze ve Stewart $(2011,5)$ artan maliyetler ve reklam bazlı azalan gelir ile artan rekabet ortamında birçok zorluğun üstesinden gelmek için kendine özgü yaratıcılığa daha fazla odaklanmaya dikkat çekerler. İnternetteki haber portalları gelişen teknolojileri kullanabilen gazetecilerin yetişmesiyle ilk y1llardakinden daha farklı bir görünüm sergilemektedir. Ancak haber maliyetinin fazlalığı ve portalların çoğunun bu maliyeti karşılayamaması nedeniyle az sayıda istihdam nedeniyle kronik sorunlar devam etmektedir.

İnternet gazeteciliği, iletişim ve bilişim teknolojilerindeki gelişmelere koşut olarak sürekli gelişen ve değişen bir gazetecilik alanıdır. Gazetecinin sürekli yenilikleri izlemesini ve kendini geliştirmesini gerektirir. (Alemdar, Uzun, 224) İnternet haberciliği için haber hazırlama prensibi çoğu kurumda Türkiye özelinde benzerlikler taşımaktadır. Katılımcıların önemli bir bölümü "İnternet için haber hazırlamak daha kolay olduğunu düşünmektedir. Görüşülen isimler, internet için haber hazırlarken kısa habercilik ve hız kaygısı ile haberciliği yaptıklarını belirtmektedirler. Haber hazırlarken linklemenin yeni davranış pratikleri içerisinde önemine dikkat çekmişlerdir. Haber seçimi konusunda tıklama kaygısının daha da ön planda olduğuna işaret emişlerdir.

\section{Yeni Çalışma Kültürü ve Teknoloji Odaklı İstihdam}

Van Dijk $(2016,96)$ İkinci Dünya Savaşı'nın ardından bilgisayarların önemli bir kontrol aracı olarak bürokrasinin yerini almış olduğunu ve yirminci yüzyılda domine yenilikçi faaliyetler olan bürokratik örgütlenme, tren, telgraf ve telefon bazlı ulaşım ve iletişim altyapısı ve kitle iletişiminin geride kaldığını vurgular. Bu davranışların yerini ikinci iletişim devrimi olarak tanımladığ 1 esnek ağ örgütlenmesi içerisinde bilgisayar tabanlı iletişim ve lojistik altyapısı ve parçalara ayrılmış ve kişiselleştirilmiş iletişimin aldığını söylemektedir. İnternet haber merkezleride bu inovasyon davranışlarından etkilenmiş kitleden bireye, mobil altyapılarla daha esnek yapılarla oluşmuş kurumlara dönüşür. Yeni medya düzeni içerisinde "yeni" kavramının bu kadar ön planda olma nedeni son 30 y1l içerisinde teknolojik anlamda tarihin hiçbir döneminde görülmeyecek şekilde yenileme davranışının artması ve yakınsama ya da yöndeşme olarak tanımlanan entegre teknolojilerin fazlalığı gösterilir. Bu yakınsama dönemi gazetecilik mesleği ile uğraşanlarda da önemli bir dönüşüme neden olmuştur. Bu dönüşüm önemli ölçüde teknolojilerin ve çalışma ortamlarının gelişmesinin mantıksal bir sonucu olarak karşımıza çıkmıştır. Gazeteciler, teknoloji bazlı bu önemli dönüşüm içerisinde yeni mesleki becerilerini ve organizasyon yapılarına adapte olmaya çalışmaktadırlar. Bugünün elektronik dünyasında, modern gazetecilik araçları başta haber toplama ve sunma, multimedya içeriği olmak üzere bilgi depolama, dizinleme ve geri çekme; işlem, üretim ve editoryal davranış dağıtım veya basım ve erişim işlevlerine sahiptir. Bu işlevler genellikle birbiriyle iç içedir ve tek bir teknik araçta bütünleşmiş edilir. (Pavlik, 2013:287) Yakınsama dönemi çoğu meslekte önemli sonuçlar gösterirken medya alanında önemli çalışma alanı değişikliği olarak tek bir yayın için yazan görüntü alan tasarım yapan araştıran gazeteci tipolojisi geçmişte kalır duruma gelmiştir. Yeni dönemin haber merkezleri editoryal bölüm içinde farklı türde işler yapabilen ve farklı 
zamanlarda çalışabilecek kadar çok yönlü gazetecileri istihdam etmeye başlamıştır. Yeni oluşan bu eğilim, son yıllarda gazeteci mesleğinin yaşadığı dönüşümü göstermek için sıklıkla kullanılır. Birçok haber şirketi "çok görevli gazeteciler" istihdam etmeyi tercih ederlerken istihdam politikası içerisinde daha düşük maaşla daha uzun çalışma saatleri içerisinde haber üretmek zorunda kaldıklarını savunuyor. $\mathrm{Bu}$ durum yöneticilerin maliyetleri düşürmek için bir "bahane" haline getireceği riski taşırken yöneticiler "Daha az imkânla daha fazlasını yapın" politikasının sonucu haber üretiminin kalitesini düşürmüştür. Bunun, teknolojinin ivmesi veya şirketlerin üretkenliği artırma ihtiyacı nedeniyle olup olmamasına bakılmaksızın, gazetecilerin artan oranda birçok değerlilik sürecine girdikleri gerçeğidir. Görüşme yaptığımız gazeteciler mekân dışına taşan çalışma biçiminde teknolojinin altını çizmişlerdir.

"Haber merkezi klasik ofis sistemi şeklinde planlanmış. Bilgisayarlar ve tablet her çalışanda mevcut. Günün her saatinde tabletler açık bir şekilde masada durur. Kişisel cep telefonlarını günün herhangi bir saatinde kapatmak yasaktır." E1

"İnternet haberciliğinde saat kavramı diye bir şey yok. Bazı günler ofis dışında da haber eklemeye ajans haberlerini takip etmeye devam ediyoruz." E 4

"7 gün devam eden bir iş yapısı içerisineyiz. Çoğunlukla az kişi ile bu işi yapıyoruz. Haber sayısının fazlalığı önemli site için. Gün içinde sürekli haber ekleme yapıyoruz." E 10

"Evden haber ekleme, serbest çalışma ortamları yaptığım için doğasında var. Bu durum bazen iyi bazen ise sorun olabiliyor." E 12

"Sosyal medya için ev ya da ofis fark etmiyor. Kitleye nasıl ulaştığımız daha önemli. Mekan sinırı artık yok." E11

"Bu işte üretkenliğin azaldığını düşünüyorum. Sürekli eklenen düz metinler. Habercilik tatmini çok değil.” E 17

Castells (2008), a ğ toplumunda yeni iş pratiklerinden söz ederken yükselişte olan eğilimin işgücünün bölünmesi ve sanal işletme ağlarının oluşumu yönündeki geniş kapsamlı eğilimin bir parçası olarak tam zamanlı ya da yarı zamanlı olarak "eve ek iş getirenlerin" ve serbest çalışanların çoğalmasından söz eder. (Castells, 2008, 528) Çalışmamızda görüşmecilerinde söz ettiği gibi evden çalışma ve ofisin dışından serbest çalışma internet haber merkezleri içinde önemli bir davranış biçimine dönüşmüştür. Standing'in yeni tehlikeli sınıf olarak nitelediği Prekarya kavramı bu yeni dönem çalışma ve emek davranışlarını karşılamak için kullanılabilir. 1980 sonrası neoliberal politikaların 'emek piyasasında esneklik' politikalarını izleme gerekliliği son kertede ücret ve istihdam esnekliği ile bugün vücut bulmaktadır. Bugün bu emek sürecindeki esnekleşme politikaları iş yaşamında güvencesizleşmenin önünü açmaktadır. Standing bu yeni dönemi şöyle özetlemektedir: (Standing, 2017, 19)

“.....Esnekliğin pek çok boyutu vardı. Ücret esnekliği talepteki değişikliklere göre bir ayarlama, yani ücretlerin düşürülmesi demekti. İstihdamda esneklik, firmaların istihdam düzeylerini kolayca ve masrafsız bir şekilde değiştirmesi anlamına gelmekteydi ve bu durum, istihdamın korunması ve istihdam güvenliğinde azalmadan başka bir şey demek değildi. İş esnekliği ise çalışanların şirket içerisinde oradan oraya transfer edilmesi ve iş yapılarının asgari muhalefet ve maliyetle değiştirilmesi olarak görülüyordu. Vasıflarda esneklik ise işçilerin vasıfları nın kolayca ayarlanması demekti..." 
Teknoloji bazlı bu dönüşüm editoryal uyum süreçleri çerçevesinde medya kuruluşlarını genellikle gazetecilerinin farklı teknolojik yapılara uyum sağlamasını bekler hale gelmiştir. Kuruluşun daha fazla beceri ve bilgi talebi arttıkça gazeteciler için endişe artmıştır.

Medya yöneticileri, çalışanlarının geliştikçe ihtiyaç duydukları ek becerileri ve uzmanlığı nasıl algılayacaklarını düşünmelidirler. Multimedya içeriği oluşturan bir dijital ortamda, gazeteciler ve diğer çalışanlar, bir ortamda uzmanlaşabilir; multimedya ortamını anlamakta zorlanırlar. (Siapera ve Veglis 2012: 33). Haber merkezlerinin editoryal ekipleri çoklu ortam üretimi için yazma, düzenleme, sunma, kaydetme ve yayınlama becerilerini geliştirmek güncellenmiş eğitsel bilgilere ihtiyaçları vardır. Yeni dönemin habercilik eğitimi ile yetişen gazeteci adayları birden çok medya platformunda eğitim görmüş ve yakınsama için daha hazır olan gelecek gazeteciler olacaklarken mevcut sistemin içinde yer alan çalışanlar ise kendi imkanları ile yeni medya düzeninin kurallarını öğrenmeye çalışıyorlar.(Siapera ve Veglis, 2012: 33). Görüşmede bulunduğumuz katılımcılardan büyük çoğunluğu mesleğin içinde iken yeni habercilik kurallarını öğrendiklerinin altını çizdiler. Yine görüşmelerden elde ettiğimiz çalışanlar da teknoloji ile bağlantılı olmanın istihdam sürecinde önemli olduğudur.

"Bu konu ile ilgili almış olduğum geçmişte bir üniversite eğitimi yok. Kurs firmalarına giderek eğitim alarak kendimi geliştirdim. Bu eğitimin üzerine, kendimi yine kendim geliştirerek ilerliyorum.” E10

"Haber merkezlerinde internet haberciliği alanında uzman kişiler tercih edilmektedir. Ancak ilgili alana istihdam etmek amaçlı eğitimler veriliyor. Bununla beraber çalışanlara internet haberciliğinin yazım dili ilgili olarak eğitimler verilmektedir." E3

"Bugün haberi eklemenin yanı sıra haberin kitleye ulaşması da önemli. Haberin okur tarafından fark edilmesi arama motorlarında önde çıkmak önemli. $\mathrm{Nu}$ konuda eğitimli, bu işin bilen kişiler daha önemli hale geldi.” E 13

İnternet tabanlı haberciliğin hâkimiyeti istihdam politikalarında da önemli değişimlere neden olmuş insan kaynaklarının yeni personel politikalarında teknoloji ile barışık olan personeller tercih edilir hale gelmiştir. Mevcut sistemin içindeki gazeteciler ise kurum dış1 eğitim ve kendi kendilerine öğrenme çabası ile kendilerini yeni habercilik kurallarına uyumlu hale getirmeye çabalamaktadırlar.

\section{Sonuç}

Gazetecilik sektöründe internet haberciliği sonrası önemli davranış değişiklikleri meydana gelmiştir. Kurumlar sürekli yazılı basın alanında kriz içerisinde iken yeniliğe ve yenilemeye odaklanmaktadır. Medya biçimlerindeki bu hızlı dönüşüm, küresel ve yerel ekonomik krizler ve okurun ihtiyaç şeklinde başta araç bağlamında büyük bir değişimin olması değişim ihtiyacını ortaya koyuyor. Yenilik yapma ihtiyacının yanı sıra, Teknolojiyi geliştirme ve kitle tercihlerini değiştirme konusunda kısa sürede daha geniş bir anlamda yaratıcılık gerekmektedir. Yenilik şu anda dünyanın dört bir yanındaki haber merkezlerinde merak uyandırıcı bir kavramdır. Teknoloji ile içerik üzerine yoğunlaşan bu araştırmada ayrıca çevrimiçi haber merkezlerinde çalışanlarının haber odası çalışma rutinleri ve teknoloji bağlamında eğilimleri gözlemlenmiştir. Haber merkezleri şu anda birçok eşzamanlı değişikliğe uğramaktadır. İnternet haberciliği 
özelinde haber hazırlama mantığının birçok kurumda benzerlik taşıdığı internet haberciliği alanı üzerine görüşme gerçekleştirdiğimiz katılımcıların önemli bir bölümü internet için haber hazırlamanın daha kolay olduğunu düşünmektedir. Görüşülen isimler, internet için haber hazırlarken kısa habercilik ve hız kaygısı ile haberciliği yaptıklarını belirtmektedirler. Haber hazırlarken linklemenin yeni davranış pratikleri içerisinde önemine dikkat çekmişlerdir. Haber seçimi konusunda tıklama kaygısının daha da ön planda olduğuna işaret emişlerdir. Görüşme yaptığımız gazeteciler mekân dışına taşan çalışma biçiminde teknolojinin altını çizmişlerdir. Görüşmede bulunduğumuz katılımcılardan büyük çoğunluğu mesleğin içinde iken yeni habercilik kurallarını öğrendiklerinin altını çizdiler. Yine görüşmelerden elde ettiğimiz çalışanlar da teknoloji ile bağlantılı olmanın istihdam sürecinde önemli olduğudur. Çalışma da özellikle teknolojinin haber yazım biçiminde dönüşümde önemli bir faktör olduğu ortaya çıkmış ve haber odasında çalışma kültürünün yeniliklere açık bireyler tarafından yürütüldüğü tespit edilmiştir.

\section{Kaynakça}

Alemdar K. ve Uzun R (2013). Herkes İçin Gazetecilik, Ankara, Tanyeri Kitap.

Atikkan Z. Tunç A. , (2010) Blogdan Al Haberi: Haber Blogları, Demokrasi, Gazeteciliğin Geleceği Üzerine, Yapı Kredi Yayınları

Barbier. F. ve Lavenir. C. B. (2001). Diderot'dan İnternete Medya Tarihi. İstanbul: Okuyanus Yayın.

Boczkowski, P. (2004). The processes of adopting multimedia and interactivity in three online newsrooms. Journal of Communication, 54, 197-213.

Briggs, M . 2007 , Journalism 2.0, available at: http://www.j-lab.org/Journalism_20.pdf (Erişim Tarihi 20.01. 2017).

Castells M. (2008). Enformasyon Çağı: Ekonomi, Toplum ve Kültür Cilt 1: A Toplumunun Yükselişi, Çev: Ebru Kılıç, İstanbul, İstanbul Bilgi Üniversitesi Yayınları.

Castells M. (2016). İletişim Gücü. İstanbul, İstanbul Bilgi Üniversitesi Yayınları.

Çakır, H.(2007) Geleneksel Gazetecilik Karşısında İnternet Gazeteciliği, Erciyes Üniversitesi Sosyal Bilimler Enstitüsü Dergisi, 1 (22).

Deuze. M.(2005). What is journalism?. Professional İdentity and İdeology Of Journalists Reconsidered Indiana University. London, Thousand Oaks, CA and New Delhi, Vol. 6 (4): 442-464 .

Deuze, M, Stewart. B (2011) “Managing Media Work.” In Mark Deuze (ed.), Managing Media Work, pp. 1-10. Thousand Oaks, CA: Sage.

Domingo , D. , Quandt, T. , Heinonen , A., Paulussen , S., Singer , J.B. and Vujnovic M. , (2008) ,Participatory journalism practices in the media and beyond, Journalism Practice 2 (3): 326 - 342 .

Kalsın, B (2016) . “Geçmişten Geleceğe İnternet Gazeteciliği: Türkiye Örneği”, The Journal 
of Academic Social Science Studies-Jass, 3(42), 75-94.

Laughey. D. (2010). Medya Çalışmaları-Teoriler Ve Yaklaşımlar. İstanbul: Kalkedon Yayınları.

Lister. M. Vd. (2009). New Media: a Critical İntroduction. New York: Routledge.

Maigret, E. (2011) Medya ve İletişim Sosyolojisi, Çev. Halime Yücel, 4. Baskı, 2014, İstanbul, İletişim Yayınları.

Pavlik, John V. (2013), Yeni medya ve Gazetecilik, Ankara: Phoenix Yayınevi.

Poe, M. (2015), İletişim Tarihi, Islık Yayınları, İstanbul.

Siapera. E. ve Veglis. A. (2012). The Handbook of Global Online Journalism, UK: Wiley-Blackwell press

Singer, J. B. (2008). "Ethnography of Newsroom Convergence", Making Online News: The Ethnography of New Media Production, New York: Roudledge. s. 157-170.

Singer. J. B. (2011). "Journalism and Digital Technologies." In Changing the News: The Forces Shaping Journalism in Uncertain Times. New York: Routledge. s. 213-229.

Standing, G. (2017) Prekarya Yeni Tehlikeli Sınıf, Çev: Ergin Bulut, İstanbul, İletişim Yayınları.

Timisi. N. (2003). Yeni İletişim Teknolojileri ve Demokrasi. Ankara, Dost Kitapevi.

Tokgöz, (2003) Temel Gazetecilik, Ankara, İmge Yayınları.

Van Dijk, J. (2016) Ağ Toplumu, İstanbul, Kafka Yayınları.

Yıldırım, A., Şimşek, H. (2008).Sosyal Bilimlerde Nitel Araştırma Yöntemleri, Ankara:, Seçkin Yayınc1lık. 